\author{
WITHIN THE FOURFOLD: \\ DWELLING AND BEING ON THE MARAE \\ Pounamu Jade William Emery Aikman
}

HE WHAKAMAUMAHARATANGA - IN MEMORIAM

I dedicate this paper to the late Dr. Cyril Timo Schäfer, without whose encouragement and kind words I would not have had the confidence to resubmit this article for consideration. Your gentleness of heart was matched only by your towering height, and I will forever remember your wit, generosity, and compassionate spirit. Moe mai rā e te rangatira. Moe mai rā.

\begin{abstract}
This article explores how Heidegger's (1971) concepts of dwelling and the fourfold are embodied within the marae (community meeting plaza of ancestral significance), as meeting centres for functioning Māori communities, and how kin who are regularly involved in their marae 'dwell' within their ancestral landscapes. Through careful analysis, I examine how the metaphysically complex nature of wharenui (meeting houses) and marae can be understood and appreciated through the alignment of the fourfold conditions of existence. Thus, wharenui uniquely reify the gathering of earth, sky, mortals, and divinities, allowing an investigation into the multifaceted nature of the marae. I conclude by discussing the primary challenge for marae today - the irregular return of kin and physically distanced whānau - and whether the process of dwelling can continue as kin negotiate the struggles of living in the twenty-first century.
\end{abstract}

Keywords: dwelling, marae, Heidegger, community, holistic

\title{
INTRODUCTION
}

'What is it to dwell?' Martin Heidegger provocatively asked $(1971,145)$, introducing his famous essay 'Building Dwelling Thinking' (Bauen Wohnen Denken) (1971, 145-61). Heidegger presented this paper to a symposium of architects 
in Germany in 1951, when a massive post-war rebuild effort was taking place and the 'dwelling question' (Wohnungsfrage) was etched firmly into the public consciousness (Sharr 2007, 21). It seems, however, that Heidegger was less concerned with the pragmatics associated with answering this need and was instead more interested in the question of what 'dwelling' really means. For, as he asserts, 'Only if we are capable of dwelling, only then can we build' (1971,160; his emphasis).

I assert that the process of dwelling is underscored in the marae (community meeting plaza of ancestral significance) complex, and a careful analysis of the marae illustrates Heidegger's gathering of the fourfold. I consider how wharenui (meeting houses) gather the fourfold of earth, sky, mortals, and divinities. Yet, in similar fashion to Heidegger's existential apprehension nearly seventy years ago, my point of departure is to ask if dwelling still occurs within the marae of contemporary New Zealand society. I begin by examining the core concepts of dwelling, building, and the fourfold as conceptualised by Heidegger, linking these ideas to the notion of place making. I illustrate these ideas with examples from my ethnographic research in two of my tribal marae in Whakatāne, in New Zealand's Eastern Bay of Plenty; conversations and interviews with whānau (family members) from the two marae (Wairaka: Te Whare o Toroa and Rangataua: Te Pāhou) form the basis of this discussion. In the final section of this article, I discuss whether marae can remain places of dwelling - of connectedness with kin, ancestors, tribal lore, knowledge, and experience - when faced with the demands of twenty-first-century living. In this way, I hope to shed some light on the challenges marae face, especially in engaging the younger generations of kin, as their hands will shape such symbols of cultural identity in the future.

DISCOVERING THE NATURE OF 'DWELLING'

Heidegger was concerned about the relationship between building and dwelling and how the two interacted with each other. We might first describe 'dwelling' as living in harmony with one's surrounding environment. To help in this pursuit, Heidegger employs etymological archaeology, excavating the hidden meanings of familiar words (Sharr 2007, 23). He reveals that the German verb bauen (to build) is a direct descendant of the High German and Old English word buan (Ingold 2000, 185), which means 'to dwell'. Heidegger explains, 'Bauen originally means dwell' and 'also means [...] to cherish and protect, to preserve and care for, specifically to till the soil, to cultivate the vine'. In other words, dwelling was more than the sum of technicalities associated with construction; it involved the careful nurturing that comes with preserving and 


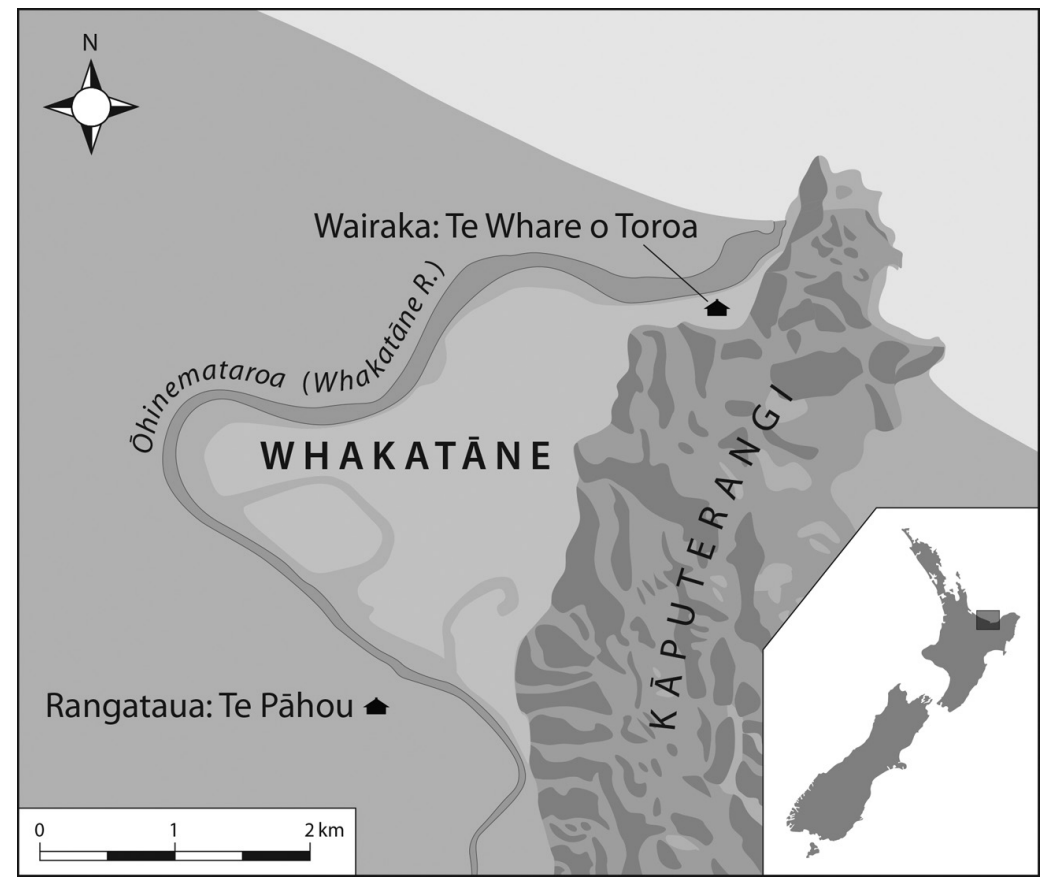

Figure 1. Map of Wairaka: Te Whare o Toroa and Rangataua: Te Pāhou. Both marae are ancestrally defined by the Ōhinemataroa River and the mountain range Kāputerangi. Source: Les O’Neill, Department of Anthropology and Archaeology, University of Otago.

cultivating the land. This aspect, he argued, was a central component of existence and a sentiment which entered language at a much earlier point:

[Bauen], buan, bhu, beo are our word bin in the versions: ich bin, I am, $d u$ bist, you are, the imperative form bis, be. What then does ich bin mean? The old word bauen, to which the bin belongs, answers: ich bin, du bist mean: I dwell, you dwell. The way in which you are and I am, the manner in which we humans are on the earth, is Buan, dwelling. (1971, 147; his emphasis)

At some period in time, therefore, 'dwelling' and 'building' defined what it meant to exist and to be in and of the world, reiterated each time such phrases as 'I am' (ich bin) and 'you are' (du bist) were uttered (Sharr 2007, 40). Heidegger's somewhat cryptic earlier statement, asserting that dwelling is a 
prerequisite of building $(1971,160)$, is at the heart of this philosophy. However, Heidegger felt that this symbiosis, this original essence of dwelling and building, had been lost in the vicissitudes of modern life. In a world ruled by technocracy, at the behest of bureaucrats and professionals, and with scientific knowledge supreme, the ability to till the soil and cultivate the vine (that is, to be directly involved in preserving, maintaining, and nurturing one's landscape of home) has become gradually eroded. For Heidegger, the 'real plight of $d w e l l-$ ing' was the disruption between dwelling and building (1971, 161; his emphasis), not, as the framing of the housing crises would suggest, the manufacture and construction of houses (Sharr 2007, 42-43).

Ingold expands on Heidegger's assertion of 'dwelling before building. He explains that buildings are created in the flow of our activity in the environment and are reflective of that relationship. In other words, to grasp the concept of building from a Heideggerian perspective is to recognise that architectural forms (structures) do not arbitrarily appear upon the landscape. They are instead reflections of the worldview and values of the people who inhabit the land. As Ingold summarises, 'the forms of buildings arise as a kind of crystallization of human activity within an environment' $(2000,186)$.

For Māori, I believe this process is anchored in place by the concept of tangata whenua (people of the land). While in common parlance today this phrase is used to denote the original inhabitants or indigenous peoples of an area or region, a more accurate interpretation of 'tangata whenua' embodied in our ancestral past literally refers to the genetic relationship a people had with their land (Tapsell 2009). In times past, the nourishment provided by the land - through staples such as kumara (sweet potato) - became part of the DNA of kin, and so their genetic makeup became embedded and solidified in the land. In this way, tangata whenua figuratively and literally means 'people of the land'. Papa-tūā-nuku is literally 'Earth Mother', as we are given life through her. This context, I believe, is fundamental to understanding the nature of marae today, as a marae is about people (tangata whenua) and their intimate connection to place. Heidegger felt that in dwelling, people became intimately aware of their surroundings and developed an appreciation of the finite nature of existence. This perspective accommodated what he termed 'the fourfold', a philosophical concept through which he interpreted the world around him. I now explore this concept in more depth.

ALIGNING THE FOURFOLD

The practice of dwelling and building is entangled with the 'gathering of the 
fourfold' (Seamon 2000, 190), or an alignment of earth, sky, mortals, and divinities. For Heidegger, the fourfold was a way to describe human existence. Its constituents can be used to make sense of the world around us and, in so doing, provide an interpretation and analysis of it (Harman 2007, 181-82; Sharr $2007,32)$. Heidegger explains the fourfold in the following:

[Dwelling] reveals itself to us as soon as we reflect that human being consists in dwelling and, indeed, dwelling in the sense of the stay of mortals on the earth. But 'on the earth' already means 'under the sky'. Both of these also mean 'remaining before the divinities' and include a 'belonging to men's being with one another.' By a primal oneness the four - earth and sky, divinities and mortals - belong together in one. (1971, 149; his emphasis)

He proceeds to describe each of the four elements in turn, defining earth as the 'serving bearer, blossoming and fruiting, spreading out in rock and water, rising up into plant and animal' (149), a description which refers to the resources, materials, and gifts of the natural environment that are bestowed upon us as humans during our fleeting time in this existence. Heidegger's sense of safeguarding and 'sparing' the earth is echoed here, urging us to preserve what is available to us as a fundamental of dwelling, and reflecting the philosopher's predilection for conservation instead of the human tendency to exploit and subjugate (149-50). Heidegger's sky refers to the 'clemency and inclemency of the weather' (149), reminding us that our dwelling is affected by the elements. When we build, there are material concerns; consider, for example, the steep angle of rooftops in snow-prone areas, designed both to withstand the substantial weight of precipitation and to encourage snow to slide off. Seamon describes the term 'divinities' as a sense of spiritual reverence $(2000,190)$, and Sharr suggests that it refers to the 'mystical dimensions of life that can't be rendered rational' $(2007,45)$. The final component - mortals - not only represents us as people or human beings (Heidegger 1971, 150), but more importantly emphasises that we live life under the continual spectre of death, in what is characterised as 'Being-toward-Death' (Steiner 1992, 104-105). Despite this melancholic appearance, Heidegger stresses that life itself is organised around the finite nature of our existence and is something to be celebrated and respectfully observed (Sharr 2007, 45).

To answer the deceptively simple question that opened this article, dwelling denotes the gathering of the fourfold with explicit regard to sparing and preserving the earth. For Heidegger, the fourfold exists within all structures in a 'mirror-play' - that is, things in the world reflect the presence of the four 
dimensions of existence (Harman 2007, 131-32). I elaborate this thought below in relation to marae.

\section{SPACE AND PLACE}

Intimately linked with the fourfold is Heidegger's concept of place (1971). Place, Heidegger says, is what the nothingness of space is transformed into by virtue of human activity, experience, and memory. Space - the natural topography, including rivers, mountains, or coastlines - becomes place when people inhabit such landscapes and imbue them with meaning. Heidegger writes, 'Accordingly, spaces receive their being from locations [i.e., place] and not from "space"' (1971, 154; his emphasis). As Gray explains, dwelling refers to the creation of meaningful places that combine to produce an environment (2003, 232). Therefore, we might speak of the Ōhinemataroa River, Kāputerangi (a defining ridgeline of my ancestral landscape), or the Whakatāne coastline as meaningful places. As we invest experience in the landscape, space transmutes into place, as "spaces" gain authority not from "space" appreciated mathematically but [from] "place" appreciated through human experience' (Sharr 2007, 51). This concept is useful for anthropological inquiry as evidenced by the considerable body of research on the topic (Cultural Anthropology 1988; de Certeau 1984; Fernandez 2003; Gray 2003; Gupta and Ferguson 1992, 1997; Low and Lawrence-Zúñiga 2003; Rodman 2003).

The process of dwelling is embedded in place when we build and construct. This process is termed by architectural thinkers the 'concretization of space' (Norberg-Schulz 1971, 6) and the 'identification of place' (Sharr 2007, 52-53; Unwin 1997, 13-17). When in the act of building, a boundary is defined within the 'nothingness' of space, and the fourfold of earth, sky, mortals, and divinities is aligned through physical demarcation (Sharr 2007, 52-53). Once a people decide to inhabit an area, the structures they build for shelter and day-to-day living metamorphose space into place. This activity is what ethnographer John Gray terms the process of 'place making' $(2003,224)$, a concept he adopts from the work of Basso $(1996,5-8)$ and Gupta and Ferguson (1997, 4, 6-12). Place can be experienced in a multitude of ways. In discussing her ethnographic fieldwork in Melanesia, Margaret Rodman explains that narratives of place 'can be told and heard with senses other than speech and hearing [...] [and] expressed [, for example,] through the sight of a rock that grew, through certain smells, in the way the wind blows, or the taste of a mango' (2003, 214-15). Gray (2003) examines this process as experienced by shepherds in the highlands of Teviothead in the Scottish Borders. He describes how shepherds transform the physical environment into a significant place of belonging, where they walk 
or motorcycle through the extensive terrain and assign meaning to or adopt established meanings for features in the landscape (2003, 231-37). This process is comparable to Heidegger's view of building, in which 'the place identified by one person can also become a place for others because of its physical incarnation' (Sharr 2007, 55). To conclude, places must be conceptualised, not with exclusive reference to the geo-technical dimensions of the environment, but according to the human activity and experience of dwelling and building therein (Sharr 2007, 55-59).

As reflected in the following section, the experiences of kin in relation to their marae demonstrate the cogent nature of these theoretical underpinnings in making sense of and understanding marae. It is my hope that this discussion will humbly contribute to the existing body of knowledge on marae (Harawira 1997; Metge 1976, 227-45; Salmond 2009 [1975]; Tauroa and Tauroa 1986), in giving voice to the contemporary realities of marae communities. I begin by clarifying some of the concepts and terminology associated with marae.

\section{A WORD ABOUT CONCEPTS AND TERMS}

While 'marae' is generally employed today to denote the wider complex of buildings - including a wharenui (ancestral meeting house), wharekai (dining hall), wharepaku (ablution block), and urupā (cemetery) - the full term is 'te marae ātea o Tūmatauenga'. Often shortened to 'the marae ātea', this term refers to the courtyard precinct in front of the wharenui, and the marae a tea is within the spiritual domain of Tümatauenga (atua [ancestor of on-going influence] of war and human interaction) (Higgins and Moorfield 2004, 73; Legge 2008, 89 ). It is in this space that debate, discussion, and similar person-to-person interactions are prescribed. The term 'marae' was traditionally applied only to this open courtyard area and not given to the entire complex, as is often the case today. However, in conversations, whānau commonly use the term 'marae' - without a qualifier - when eliciting either meaning, and the specific connotation is provided by the context. While my whānau are able to do this with ease, it can cause confusion amongst those unfamiliar with marae.

In speaking with whānau, I noticed that elder generations preferred to speak of the ' $p a \bar{a}$ and 'papakāinga' (fortified village) when referring to the marae complex, which helped to distinguish between the complex and the marae àtea. A papakainga was originally a fortified village complex, and the marae antea was central to the papakāinga as it functioned as a space from which rangatira (chieftains, leaders) exercised their social, political, and economic influence on the surrounding region (Tapsell 2014, 42-43; Tapsell and Woods 2008, 197). 
'Marae,' pāa, and 'papakāinga' were used synonymously and interchangeably by many of those I interviewed. Koro and kuia (male and female elders) often mentioned that what I (as a rangatahi or youth) call the 'marae', they would call the 'pā'. In particular cases, however, a marae may be referred to by the name of the marae atea or by the name of the wharenui, the latter being the case for both marae discussed in this study. Thus, while Te Whare o Toroa and Te Pāhou are the full names of both marae, 'Wairaka' and 'Rangataua' are used respectively to identify their marae complexes. Wairaka and Rangataua are eponymous ancestors within each of these kin communities and have been rendered immortal through their representation as wharenui. In the conversations and interviews held during my research, Wairaka and Rangataua were often the preferred terms of use.

It is important to recognise that, when we speak of marae, we are referring both to a complex of structures upon an ancestral landscape and to a community bound together by descent and kinship. Descent through whakapapa (genealogy; layering) allows an individual to be linked to numerous marae in a specific region; I am connected through my paternal lineage to the two marae in this study, Wairaka and Rangataua. The kin community of a marae is often known as the ahi kā roa (literally, long burning fires of occupation, which denotes those that keep the marae alive) or the hau kāinga (home people, local people who maintain and keep the marae alive). If one assumes that the distinct gabled architecture of a wharenui is all that encapsulates the marae, then he or she disregards the ineluctable fact that a marae is its people. As one of my whānau aptly pointed out, 'a [marae] without people makes nothing.' I emphasised the overwhelming importance of this fact in a poem I composed about my research for the Three Minute Thesis competition: ${ }^{1}$

For a marae is more than just a shape, a structure, or a place It is the legacy of our ancestors that brings us face to face. (Aikman-Dodd 2013)

The structures of a marae are but a corporeal reflection of the dozens of generations that have gathered where kin do today, allowing the living to commune with their ancestors. In other words, referring to 'our marae' is as much a comment about the physical complex as it is about the home community who keep the fires burning. The two are entwined symbiotically and cannot be studied in isolation from one other. To Wairaka and Rangataua, I now turn, describing the process of dwelling in these marae communities. 
Ko Kāputerangi rāua ko Pūtauaki My mountains are Kāputerangi and ngā maunga

Pūtauaki

Ko Ōhinemataroa te awa

My river is Ōhinemataroa (also known as the Whakatāne River)

Ko Mataatua te waka

My ancestral canoe is Mataatua

Ko Ngāti Awa te iwi

Ngāti Awa is my iwi (tribal affiliation)

Ko Ngāti Hokopū rāua ko Ngāti Wharepaia ngā hapū

Ko Te Whare o Toroa te marae

Ko Wairaka te whare tipuna

Ko Tamatea ki te Huatahi te wharekai

Ngāti Hokopū and Ngāti Wharepaia are my hapū (subtribal affiliations)

Te Whare o Toroa is my marae

Wairaka is my ancestral meeting house

Tamatea ki te Huatahi is the wharekai

Ko Te Mānuka Tūtahi te whenua. The ancestral lands of my marae are known as Te Mānuka Tūtahi.

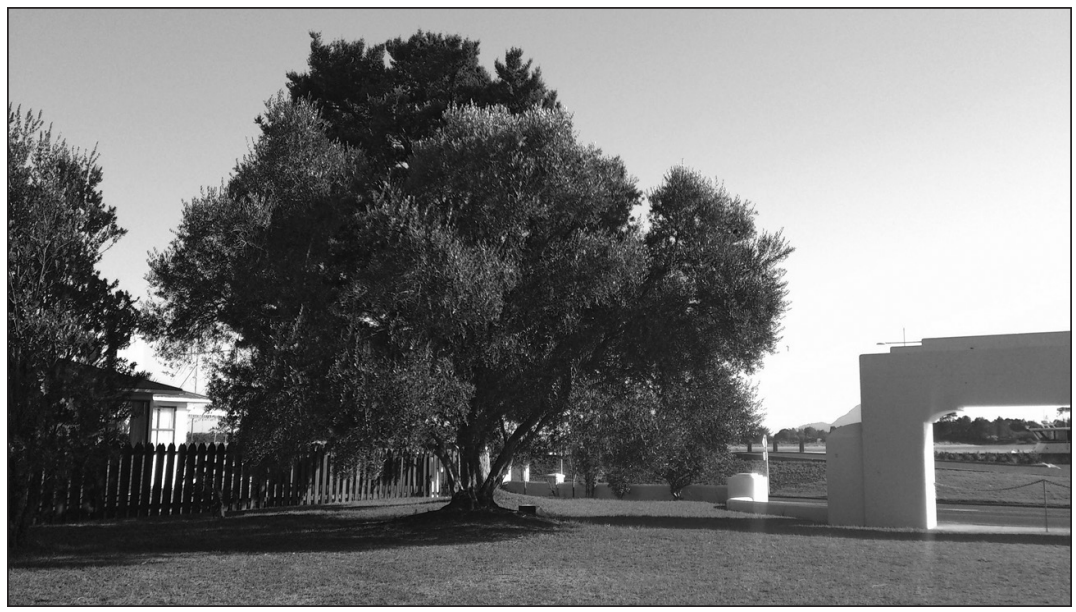

Figure 2. The olive tree on the marae àtea behind the waharoa, honouring the sacrifices made by kinsmen from Wairaka in Europe during World War II (particularly in Crete). Source: personal collection. 
I open with my pepeha (tribal introduction), which locates Wairaka amongst its physical and social landscapes, identifying the component parts by name. By doing so, it weaves together the ancestral features of the environment with the lived experiences of present-day kin, which, for me, is articulated each time I recite my pepeha. When I return to Wairaka, I am greeted by the flow of Ōhinemataroa, the steadfast silence of Kāputerangi flanking behind, and the wharenui Wairaka gazing out upon the oceanic horizon.

On a hot day in April 2013, I journeyed through the small cluster of Whakatāne shops to return to the marae for the first time since I started university. As I neared, a large white concrete arch (the entrance or waharoa) welcomed me, behind which lay an expansive grassed area (the marae ātea) lined on its borders with elongated benches. A little further beyond stood the wharenui itself, and I whispered a quiet greeting to Wairaka and my ancestors before entering the marae. As I began my slow march onto the marae àtea, I paused briefly beneath the shade of the distinctive olive tree to my right, the seed for which was gifted by families of Crete to honour the soldiers from Wairaka who valiantly fought on the Mediterranean island during World War II. New Zealand soldiers were significantly involved in the battle for Crete (King 2012 [2003], 398 ), and today the mature olive tree, a distinguishing feature upon Wairaka's àtea, blooms each season as a reminder to living kin of the sacrifices tūpuna (ancestors) made on foreign battlefields.

This short introduction illustrates the experience of place amongst Wairaka. My pepeha reflects a lineage of place-making by generations of ancestors, recent and distant, gradually ingraining knowledge in the physical landscape. The stories, struggles, heroes, and triumphs of the marae community are reified by representation within physical markers, such as the defining mountain of Kāputerangi and the olive tree upon the ātea. This practice embodies Anne Salmond's assertion that, for Māori, specific knowledge is interwoven with and embedded within landscapes $(1982,84)$. Anchored by the physical boundaries of the marae, these stories are transmitted from elder to youth and memorialised intergenerationally. They are reminders of those who dwelled before (Sharr 2007, 54), transforming the geographic environment into a compelling place of belonging. Wairaka's story of origin, which I turn to next, sharpens this theoretical and philosophical focus.

Wairaka: Story of Origin

The wharenui is named after the great Ngāti Awa ancestress Wairaka; Wairaka: Te Whare o Toroa is one of the few marae in New Zealand to have its wharenui 


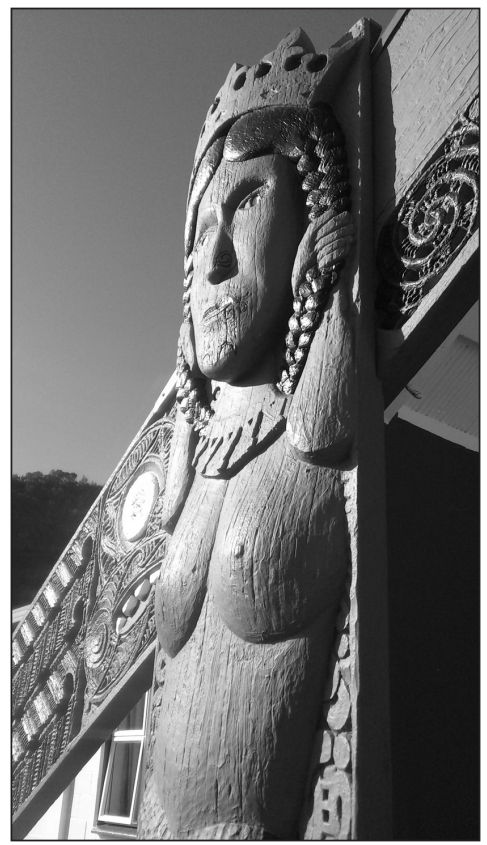

Figure 3. The carved figure of Wairaka on the front of the wharenui. Source: personal collection.

named after a woman. The following Ngāti Awa legend of origin, retold to me through the oral history of my whānau, helps explain why she has been celebrated in this way. ${ }^{2}$ Wairaka was the daughter of Toroa, who captained the Mataatua waka (great voyaging canoe) on its journey to New Zealand in roughly the twelfth century. After traversing the Pacific ocean, Mataatua reached the mouth of what is today the Ōhinemataroa River. Aboard the waka were the groups' resources and possessions, which, in short, represented their livelihood. After the men disembarked and went to scout the land, the women and children were left on the shoreline. In time, the rising tide lifted the waka from its mooring, causing it to float back out to sea. A quandary arose: tradition decreed that only men could handle the waka and its hoe (paddles), but the men were absent from the beach. In this moment of crisis, Wairaka was forced either to break this custom or to watch her people's livelihood disappear over the horizon. Fearing the loss of the waka, she picked up a hoe and thrust it into the ground. She then cried, 'Kia whakatāne au i ahau!'(Let me act the part of a man!). Heaving on the mooring ropes still tethered to the waka, Wairaka secured them to the grounded hoe to rescue the waka from its 
seaward drift. So her people lived, and so do the dynasties of Ngāti Hokopū and Ngāti Wharepaia. Today, the marae stands a few dozen metres from where Wairaka saved Mataatua, and she has been forever memorialised in the names of both the wharenui and Whakatāne.

Retold as a defining epic of cultural history, this story recounts the beginning of distinctive Ngāti Hokopū and Ngāti Wharepaia tribal identity. As a creation narrative, it illustrates the decision to settle in this particular spot in space, and the recitation of pepeha reflects the generations of tūpuna who have dwelled in this particular location before. In time, settlements were established, and the physical environment became gradually permeated with oral histories. The physical structures of the wharenui and marae complex we see today are the most recent reflections of this dwelling, taking their form in response to socio-political and economic tides, particularly colonisation. From a Heideggerian perspective, the individual and collective kin experience of dwelling has become inscribed in place through the physical delineation from the natural landscape and the construction and upkeep of the marae. This inscription is an ongoing process, and I continue to explore this subject below.

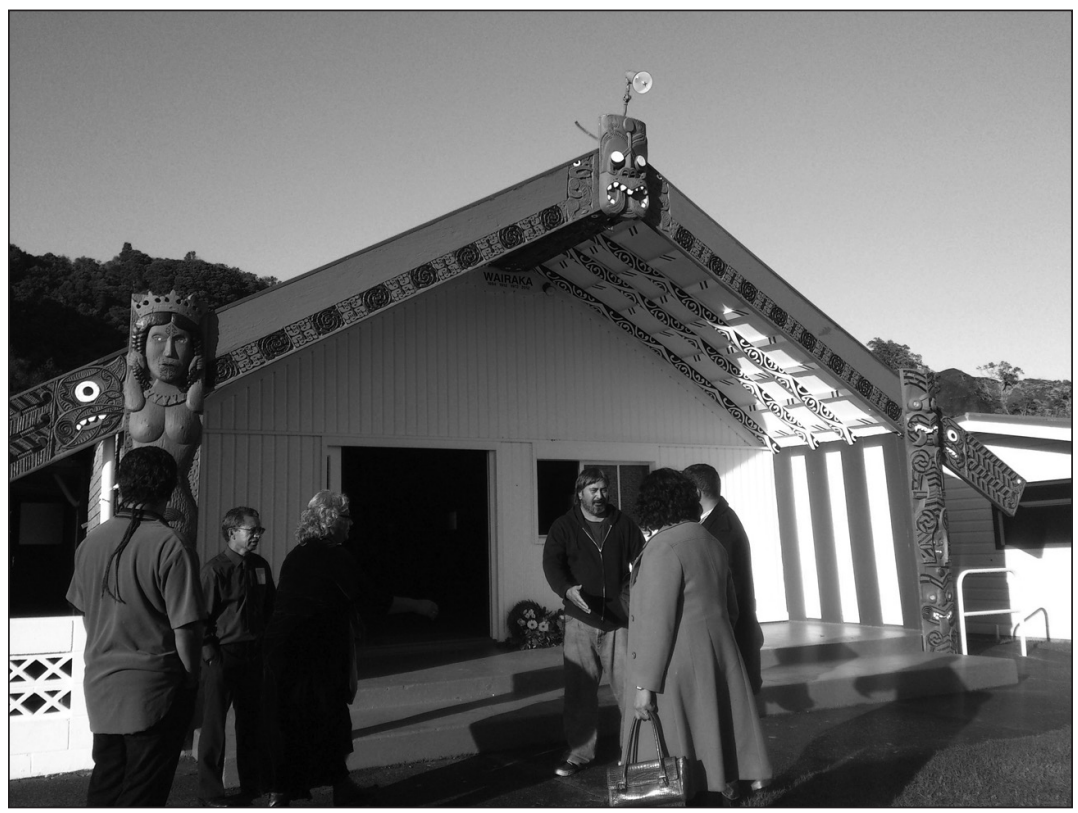

Figure 4. Kin assemble beneath Wairaka during the ANZAC Day celebrations of 2013. Source: personal collection. 


\section{Community Drives to Ensure the Wellbeing of the Marae}

The effort the hau kaiinga of Wairaka expend in the cultural, spiritual, physical, and economic running of the marae are significant. Maintaining the marae is a crucial task, from mowing lawns and organising marae bookings, to ensuring that power bills and rates are paid. Charlie, one of the kaumātua (male elder) I spoke with, highlighted the substantial financial impositions placed upon Wairaka, adding that, when he was growing up, 'anything that we did to maintain our marae was done through our own efforts. This observation remains as true today as it was during Charlie's youth.

Despite these challenges, the collective resolve to ensure the survival of Wairaka became very apparent during my numerous discussions with kin. Kuia ( $f e-$ male elder) Hine explained to me that,

to build the wharekai at Wairaka [in the late 196os], all the whānau bought one dollar bricks [...] if we have to go back that way to keep it maintained, you know, the whānau putting a dollar in, that might be what has to happen. But that's how our community thought then to help build our wharekai, they actually bought one dollar bricks to help build it [...] If it has to come back that way, I'm sure our community [would do this].

Hine contributes greatly to the upkeep of the marae, both in an executive capacity (she is on the governing committee of the marae) and on a daily basis (such as regularly working in the kitchen during events). As she continued to explain, many items in Wairaka's inventory for the kitchen and wharenui (such as tea towels, sheets, and pillowcases) are running low, and so she and some others initiated a 'sheet and tea towel drive'. Whānau were encouraged to buy two tea towels for the marae and to donate a few dollars towards purchasing new sheets, which has helped to replenish these stocks. Hine's words exemplify the collective determination to see the marae continue to live and thrive. She said, 'it's our marae and its always going to be there, it's not going to go away. We've got a good little group down there keeping the place going. This determination both reflects the central importance of Wairaka to Hine and the rest of the hau kāinga, and drives the community's efforts to preserve their marae.

\section{The Rangatira: Rangatahi Dynamic}

In similar fashion, whannau reiterated the axiom that 'the front cannot operate without the back', a statement that epitomises the complementary nature 
of how kin contribute to the preservation of the marae. What we see in the front (the ornately carved wharenui and the adjacent wharekai) can only be maintained by the other facilities behind, such as the kauta (kitchen), wharepaku (ablution block), hāngi pits (earthen ovens), and other storage buildings. Likewise, we are mistaken if we assume that the publically visible individuals of a marae, such as the kaikōrero (formal orators) and others who perform during the pōwhiri (ritual welcome), are the only leaders therein. The ringawera (kitchen hands; literally, hot hands), those on the executive committee (secretaries, treasurers, and so forth), manual labourers, and general helpers provide the vital infrastructure that ensures the day-to-day functioning of the marae. They are the leaders in their respective spaces; they are what Sir Hugh Kawharu identified as kin contributing their specific area of technical proficiency to the maintenance of marae $(1975,67-70)$.

When discussing the 'domains of expertise' upon Wairaka, Charlie referred to the 'rangatira: rangatahi' (chieftain, leader: youth) dynamic. He stressed that leadership is not centralised in one entity upon the marae (as in a hierarchy with a rangatira or Prime Minister at its apex) but is instead exhibited within all domains of Wairaka. Thus, while one may be a rangatira in one realm (such as kaikōrero), that does not determine one's rangatira status in other areas of the marae (such as in food preparation). More importantly, this system necessitates a relationship of mutual respect, in appreciating each of these domains of expertise. As the experience of marae is a sum of its parts, illustrated through events such as hosting (from those engaged in whaikōrero [formal oratory] through to those preparing the food), the qualities of leadership permeate all segments of its being. Charlie captures this essence:

I listened to [a kaumātua who] was giving a kōrero [an address] at the marae actually. And he was [talking about] the concept of 'rangatahi' and 'rangatira.' We have this perception of rangatahi as being 'young people', and our perception of rangatira as being old people. Now, on certain aspects of the marae, āe [yes], yes there are. But what we have to understand is that there are positions on the marae that are pertinent to the rangatira of that particular part of the marae. So, me, I sit in front. So I'm regarded as one of the rangatira of the marae because I'm out in front and people see me. So they have that perception of me as being the rangatira o tēra marae [one of the chiefly leaders of Wairaka]. Well, kei te tika [in that respect, that is true]. But, you ask me to go and prepare the hāngi, for argument's sake. Kāo [no]! I mean I can do it, but I'm not the rangatira of that, no. There's a rangatira at the back that may be half my age but he's 
the rangatira, and I'm the rangatahi when it comes to that particular part of the mahi [work] of the marae. Very, very important. In the kitchen - preparation in the kitchen - don't ask me to do all those things because I don't know [how to do] them! But those ladies in there $[. .$.$] are the rangatira. I'm the rangatahi [within that domain].$

For Charlie, therefore, the marae is a vibrant tapestry of interwoven strands of leadership, and within each domain the rangatira: rangatahi dynamic exists. This dynamic is fundamental to the everyday operation of the marae and reflects the level of energy invested by the hau kāinga to ensure that the home fires remain burning. I believe such examples and dynamics, which occur at the grassroots levels of Wairaka, demonstrate the process of dwelling.

Gray asserts that dwelling 'privileges the practical and the spatial in the constitution of knowledge and meaning. The formative acts of dwelling and knowing are doing things with objects, picking them up, manipulating them, and discarding them' $(2003,232)$, and this assertion is embodied in Wairaka. Each tea towel folded, each tree trimmed, each meal prepared, and each dollar raised in support of the marae bind kin in a constant process of place-making and dwelling, in preserving and cherishing the land, in essentially tilling the soil and cultivating the vine (Heidegger 1971, 147). The hau kāinga are directly and intimately involved with their environment - a prerequisite of dwelling (Gray 2003, 232; Heidegger 1971) - and are seen to be 'using the world' instead of scrutinising it as they go about stoking the fires of home (Thomas 1993, 28). These few fieldwork snapshots illustrate how the hau kāinga cherish, protect, and preserve the land and the marae and how they are literally dwelling in their ancestral landscapes as they continue to imbue place with meaning.

The question that remains, however, is, Will this process continue despite the challenges of modern society? I will discuss this question shortly, but first I examine my fieldwork within the hau kāinga of Rangataua. I will begin by briefly summarising how the two marae are related and how I came to conduct my research amongst the Rangataua community.

Whānau of Wairaka and Rangataua share Merito Hetaraka as a common ancestor, with distinct lines of Merito and Hetaraka families descending from him (adopting his first and last names as surnames). Cousin Jo of Rangataua is a Merito through her maternal lineage, and she explained that the Merito whānau first established themselves at Wairaka before moving upriver to Rangataua. As she describes, 'the Merito whānau's initial papakāinga was Wairaka, until they moved inland to [Te] Pāhou'. For much of my life I was not aware 
of this ancestral connection, nor had I been to Rangataua before. When I returned to Whakatāne for my Master's research, close friends and extended whānau bridged this gap by inviting me to speak with whānau from Te Pāhou and hear their experiences. Jo was kind enough to take me on a guided tour of the marae on an equally tropical April day in Whakatāne, and she introduced me to whānau who were busily working in the surrounding paddocks. In the course of our numerous conversations, I became aware that, while Rangataua and Wairaka are both within the administrative ambit of Te Rūnanga o Ngāti Awa (Trona, the Ngāti Awa Tribal Council), ${ }^{3}$ Rangataua is not of the Ngāti Awa tribe (as is often mistaken). Those who belong to Rangataua proudly assert Ngāti Pūkeko as their iwi, and their tribal identity is fiercely articulated along such lines. Although oral histories and whānau stories of Rangataua and Wairaka may differ, both are ancestrally defined by Ōhinemataroa, Pūtauaki, and Kāputerangi and are in proximity to one another with the flow of the river linking them (see Figure 1). It was a privilege to have been welcomed so hospitably into the hau kāinga of Rangataua, and the rich diversity of their experiences is explored below.

RANGATAUA: TE PĀHOU

Ko Pūtauaki rāua ko Kāputerangi ngā maunga

Ko Ōhinemataroa te awa

Ko Ngāti Pūkeko te iwi

Ko Rangataua te marae

Ko Hinekete te wharekai

Ko Ngāti Rangataua te hapū
The ancestral mountains are Pūtauaki and Kāputerangi

The river is Ohinemataroa

Ngāti Pūkeko is the tribe

Rangataua is the marae

Hinekete is the wharekai

Ngāti Rangataua is the hapū

\section{Rangataua: Story of Origin}

This Ngāti Rangataua pepeha ancestrally defines the kin community of Rangataua, situated in relation to its mountain, river, tribe, and sub-tribe. Rapata, one of the principal kaumatua of the marae, specified that, while Rangataua is the name of the wharenui, Te Pāhou describes the entire marae complex. He further explained that Rangataua, the eponymous ancestor of the tribe, was born in Taneatua, a short distance away from where Te Pāhou stands today (in the hinterlands of Whakatāne). Rangataua's wife, Hinekete, has been memorialised as the wharekai wedded to the wharenui. First established in 1908, 


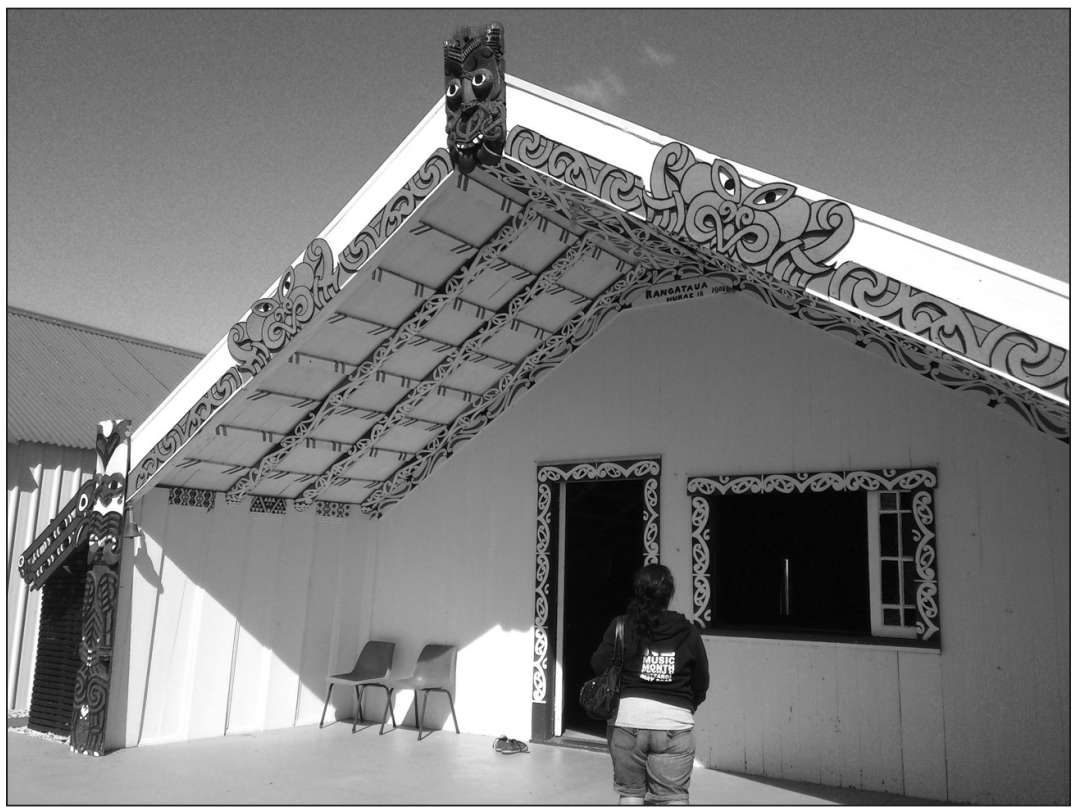

Figure 5. Cousin Jo takes me to explore the wharenui, Rangataua. Source: personal collection.

Rangataua sits on reclaimed swampland which was transformed during the agricultural intensification of the early 19oos. The marae is situated atop an elevated hill area, and, should flooding occur (which is common in the district), the water only touches the edge of the adjacent road. In 2008, to commemorate the centenary of Rangataua, the popular television programme Marae DIY (aimed at revamping and reinvigorating marae throughout New Zealand) filmed an episode at Rangataua, which resulted in substantial maintenance and structural reconditioning. ${ }^{4}$

Rangataua's centennial commemoration also recognised the challenges the marae has negotiated throughout the century. From 1974 to 1976, the wharenui served as the local Catholic church, as the actual church had fallen into disrepair. As kuia Erica and Rapata reported, in 1976 the marae was closed, and 'from 1976 to 1979 [...] it was a hay barn'. The doors of the wharenui were opened, and it became a barn which animals wandered in and out of. As Mihi Takotohiwi noted in the late 1970s, 'both [the wharenui and wharekai] were in such a dilapidated state when I saw the marae in 1977, it would not have been in a good enough state to be used by anyone' $(1980,55)$. Once it was rebuilt, 
however, the wharenui was reestablished as an ancestral meeting house for the kin community of Rangataua.

In 1979 the wharenui was reestablished, and the wider marae complex of Rangataua was symbolically reborn. A few dozen metres down the road stands Pūkeko marae, and in 1979 the wharekai at Pūkeko was demolished to make way for a new one. Rapata described how, instead of being dumped by trucks at the refuse station, the floorboards were sent to Rangataua to be laid in the wharenui. 'From 1979 [with] the floor boards coming from [Pükeko]', Rapata explained, '[Rangataua] came back to life again'. Retaining the original floorboards from Pūkeko reinforces the link between the two marae, as both are
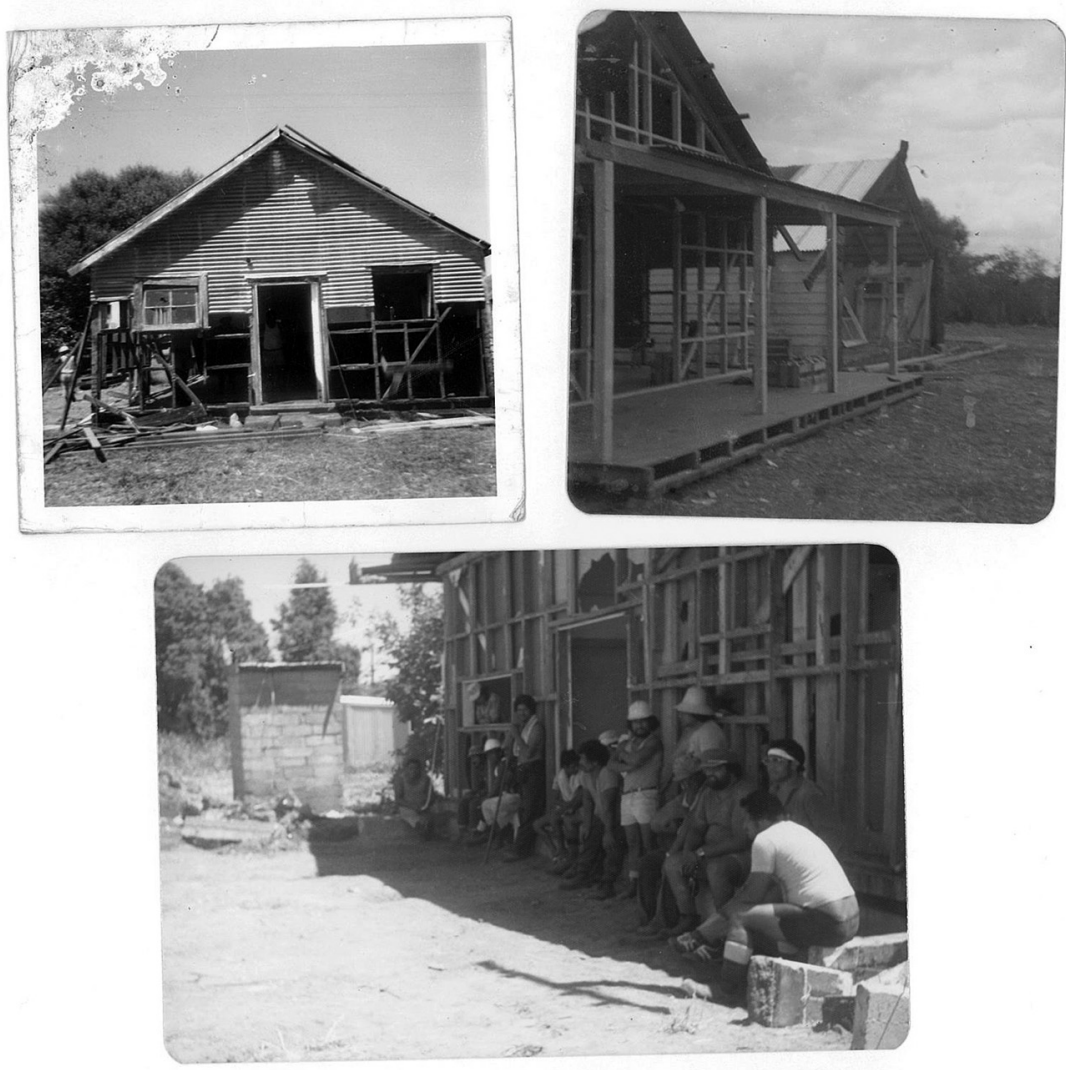

Figure 6. The wharenui in various stages of reconstruction during the 1970s and 1980s. Images courtesy of the Herangi whānau. 
of the iwi Ngāti Pūkeko. Indeed, the effort that Rangataua's community has expended to ensure the reawakening of the marae is remarkable. Heidegger's predilection for preserving the land and tilling the soil is as relevant here as it is for the hau kāinga of Wairaka. Tactile interaction with the surrounding world is an important characteristic of dwelling (Gray 2003; Thomas 1993), and, for Rapata and his hapū, this characteristic is potently exemplified by the wharenui's restoration. Although the wharenui was briefly repurposed as a church and barn, its reconstruction allowed the marae to function again, regenerating the dwelling process of the hau kāinga.

\section{The Centrality of Rangataua to its Descendant Community}

In talking with whānau of Rangataua, the regard in which the marae is held became immediately clear. Growing up, Erica lived with her parents at their homestead, a paddock away from the marae. She says that Rangataua was 'the focal point of our community, and everything that happened in the district happened at the marae': meetings were held, children were fed, and life and death were celebrated through weddings and tangihanga (rituals of farewell). A generation on, Erica's daughter Jo and nephew Waata see the marae as a critical element in the identity of the descendants of Ngāti Rangataua. Jo also lived in the family homestead as she was growing up. As the marae was in close proximity, she felt it was 'always there [... and] it was just another playground'. On Rangataua Jo met uncles, aunties, and cousins, and, although she 'never acknowledged it as a big thing, it was just always there'. In other words, there was no need to acknowledge formally the importance of Rangataua, as it simply was: it was a central part of Jo's upbringing, and later in life she came to realise that it was something of great importance. In discussing the essence of marae, Anne Salmond captures their importance:

[People] hold their weddings, twenty-first birthdays and funerals [at their marae]; the meeting-house is carved with representations of their ancestors, hung with family portraits, and named after a major leader or event in the past. Their forebears are buried nearby, and they in their turn will be also. The marae symbolises group unity, and acts as a bridge to the past as well as a useful community centre in the present. (2009 [1975],31)

Waata shared similar insights, noting that he and his whānau 'were always [at Rangataua], even as little kids'. He lived with his grandparents, but others in his family were not as involved in the marae growing up. This lack of involvement is true of many Māori who have grown up away from their ancestral 
homelands - particularly in urban areas, where tribal marae are often seen as physically and spiritually distant phenomena (Tapsell and Woods 2008, 198). Waata acknowledged that Rangataua is not as central for many of his cousins and relatives as it is for him, Jo, and Erica.

Rangataua is of great importance to Jo because of the genealogical heritage and kin-identity for which the marae stands. She describes this connection:

I used to think before, 'Why do we acknowledge [our maunga (mountain)]?' [...] My uncle [...] sat me there [upon the marae], and he said, "Look at the mountain'. And I'm going, 'Oh yep' (looking at Pūtauaki), and he goes, 'because your ancestors used to look at that mountain'. You know, and then I [understood]. It's just putting stuff into perspective. You know, that your awa has been flowing there, you eat from there, you bathe from there, you know, not only you but your ancestors did, your Nan did [...] the mountain will be there for amine [for eternity], and it was there before you, so you're looking at that maunga and so did your [tūpuna]. They used to pray there, look at there, climb there, gather food off there. That would be the same I'd say at the marae [...] my daughter's whenua [placenta] is [buried] there. Mine is there [too] [...] it's going to be there [forever].

Jo reiterates the innate genealogical connection embodied within Rangataua, serving as a reminder that the landscape around the marae has been home to countless prior generations. Within the marae, kin commune not only with the living but also with all those who have passed away. Over time, knowledge is passed from elder to youth: how to make rewana bread (sourdough made from potato and yeast extract, a staple food on marae), how to eel, and how 'uncle kills a [cattle] beast' - these three examples were provided by Jo and Erica. Prior to the world wars of the twentieth century, many Māori shared such realities because the marae was central to everyday life (Tapsell 2014, 35-64). The collective experiences of innumerable generations have become layered upon the landscape, and these experiences are anchored in place by the marae itself. This whakapapa continually evolves as kin transition from youth to elders, their experiences gradually permeating the environment.

\section{A HEIDEGGERIAN ANALYSIS OF MARAE}

Sharr's (2007) discussion of Heideggerian thought is helpful at this point. Sharr asserts that 'every structure bears the imprint of successive layers of dwelling' and that the physical manifestation of building creates a continuity of mean- 
ing in place, assertions that are explicitly embodied here and reified through the physical manifestation of the wharenui $(2007,70,55)$. This thought connects with Rodman's (2003) earlier observation that narratives of place can be experienced in various ways: when a youth transmits oral histories she heard recited by kuia and koro when they were 'young whipper-snappers on the marae, she becomes actively engaged in the chronicles of life that are interlaced with the marae and its surrounding world. Such stories are necessary to transform space into place, and both marae communities reflect the dwelling process. The hau kāinga of Wairaka and Rangataua invest considerable energy in their marae, whether by virtue of growing up there or maintaining it for present use. For all of those I spoke with, the marae was their place of childhood. They became familiar with the environment as they grew up and knew, for example, where the best spots were for catching eels and harvesting watercress. At an earlier time, the construction of the wharenui and marae concretised place, and the collective experiences of kin (both present and departed) have contributed to the dwelling-come-building paradigm. As noted, the marae was the central plaza for many people growing up, and, through dwelling, the processes of building (including the ongoing maintenance of the marae) have been stimulated, epitomising Heidegger's assertion that 'Only if we are capable of dwelling, only then can we build' (1971, 160; his emphasis).

The wharenui have undergone extensive reconstruction, as both were badly damaged during their lifetimes. (Wairaka was gutted by fire in the early 1970s, and, as discussed, Rangataua has experienced a number of 'repurposings'.) These building processes are a reflection of dwelling and the counterpart need to build, both in the initial stages of construction when the marae were first built and in the ongoing maintenance today. I return to a critical point: Heidegger was primarily concerned with the disenfranchisement of dwelling in relation to building: those who dwell are often not those who build and have therefore lost the essence of what it means to be in and of the world. For Rangataua specifically, whose hau kāinga were physically involved in reconstructing the marae through recycling floorboards from Pūkeko, this process has been briefly reversed. Of course, our analysis extends well beyond this literal approach because to dwell and build necessarily includes nurturing and carefully cultivating the land. In this sense, all of the energy invested in the marae by their respective hau kāinga is essentially preservation-in-action: cleaning the wharenui, mowing the lawns, and organising the marae for hui (gatherings) all contribute to the tilling of the land. This work reinforces the notion that buildings are processes that require continual input and maintenance and are not static structures that lie dormant in space (Ingold 2000, 188). Therefore, whether using a hammer to nail up a new weatherboard or fielding calls about 
marae bookings, the hau kāinga are always building. An integral part of building, maintenance is about preserving the physical structure in perpetuity. To dwell is to build, which is to say that to build is to preserve and maintain the land. What I have discussed thus far in relation to Wairaka and Rangataua exemplifies these theoretical insights, and the intimate involvement of the hau kāinga has fostered a distinct sense of dwelling therein. The challenge, as I have alluded to, is continuing the place-making and dwelling processes in contemporary society, and I will soon turn to this question.

\section{RETURNING TO THE FOURFOLD}

Dwelling has been inscribed physically on the landscape through the initial and ongoing processes of building within Wairaka and Rangataua. Before launching into an analysis of how marae gather the fourfold, I will briefly examine what is meant by 'gathering.' Heidegger's philosophy made a conscious break from the prevailing philosophical thought of the time that saw the individual as an objective observer existing in a separate reality. Objects - such as the laptop I'm writing on or the fire I'm sitting beside - were likewise characterised by this detachment. Instead of conceptualising objects in abstract terms essentially divorced from human activity, Heidegger suggested that the paraphernalia of life (what he termed 'things' [1971, 177]) should be understood in the context of their instrumentality and human use (Sharr 2007, 29, 46). In other words, things become things when they are involved in human activity and are engaged with according to the purposes for which they were designed. In this way, things - such as the fireplace - have a gathering effect, because they rally human presence around them. More importantly, things gather the fourfold, because they bind together earth, sky, divinities, and mortals (I discuss this in more depth shortly). Heidegger saw no distinction between 'things' and 'buildings' because they both gather human presence, and buildings gather the fourfold (Heidegger 1971, 177). Therefore, I assert that marae, as built things, gather the fourfold. Allow me to expand on this.

As a hub of activity, a place to celebrate life and death, a space in which to play with cousins and adventure up nearby maunga, marae are metaphysical and corporeal structures that gather human presence. This effect is evident in the insights of the hau kāinga offered earlier in this essay, where kin have gathered and continue to gather around the 'built thing' of the marae. More importantly, however, wharenui mirror Heidegger's fourfold conditions of existence.

The wharenui of both marae, Wairaka and Rangataua, reflect the earth through the resources and materials used in their construction and maintenance. From 
the foundations of soil and concrete, to the floorboards, carpet, and corrugated iron roofing, both wharenui gather the earth. The giving and providing nature of the earth is reflected in the geophysical location of both marae (Heidegger 1971, 149). Kāputerangi and the Ōhinemataroa River flank Wairaka, with Kāputerangi serving as a natural partition that provides shelter and security as well as an escape route to high ground in emergencies (see Figure 7). In
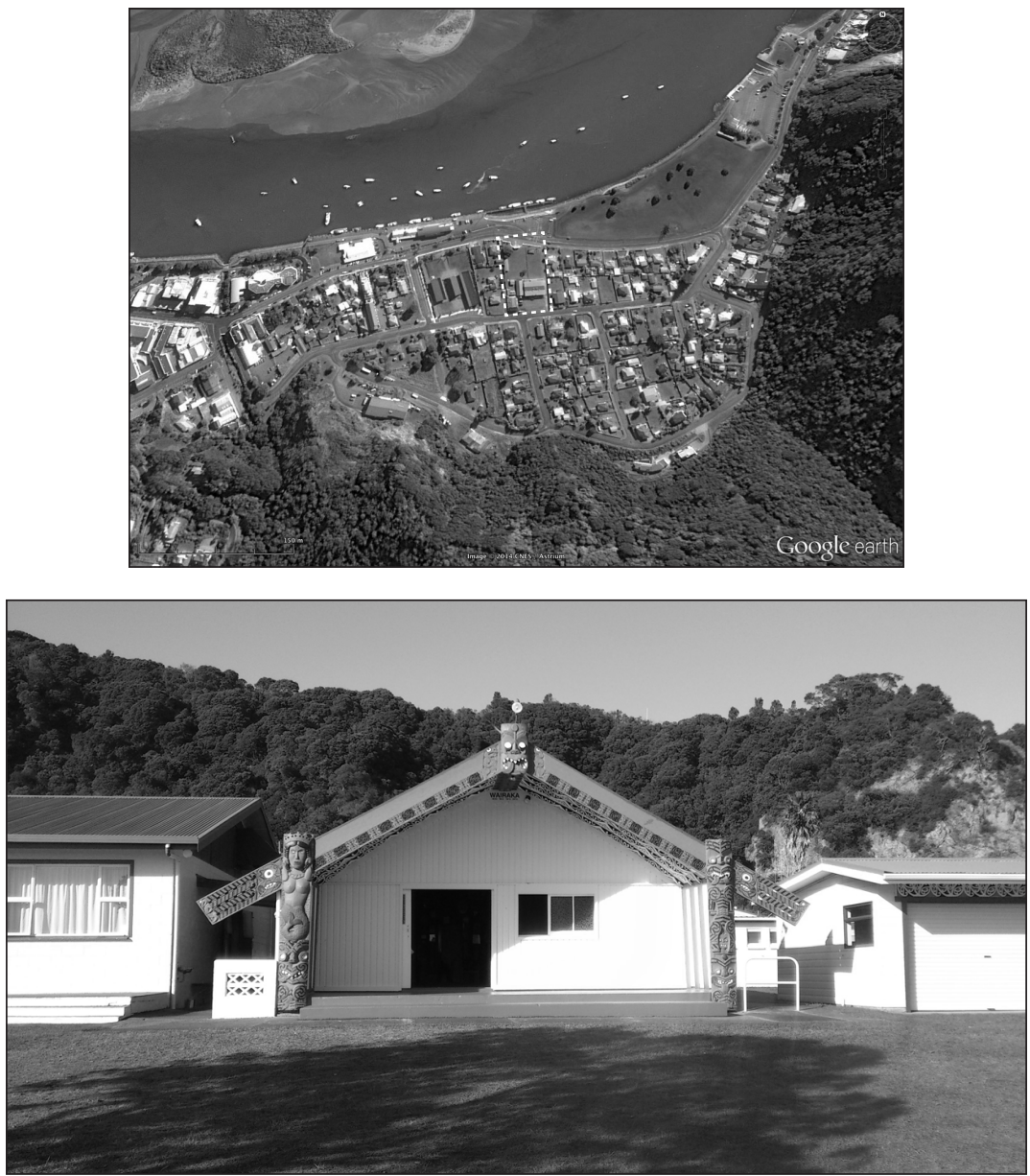

Figure 7. Above: Aerial view of Wairaka (dashed white line). Close by and flowing out to sea is Ōhinemataroa, while Kāputerangi stands guard behind the marae. Source: Google Earth 2014 CNES/ Astrium. Below: The front elevation of the wharenui delineated by Kāputerangi in the background. Source: personal collection. 
comparison, Rangataua is fittingly situated on slightly elevated land to protect the marae during seasonal flooding. The marae are connected by the flow of Öhinemataroa, which provides sustenance through irrigation and, in times past, was also a means of transportation.

Rangataua and Wairaka similarly gather the sky. The functional design of both wharenui is to shield those who dwell within it from the rain and wind, protecting them from the elements, with the distinct gables of the wharenui practical in repelling heavy precipitation. In earlier times, the high ceilings allowed the air to circulate when fires were lit inside the wharenui for warmth: smoke would rise and be vented, leaving a constant pocket of breathable oxygen at ground level (Tapsell 2009). The legacy of this functionality is reflected in the architecture of today's wharenui. This example is similar to Heidegger's Black Forest farmhouse, an example he uses in concluding 'Building Dwelling Thinking. He describes how the farmhouse gathers the fourfold: the sweeping German mountains (earth) provide shelter, and the roof's purpose is to bear 'the burden of snow' (sky) (Heidegger 1971, 160). During the heat of the summer, the doors of Wairaka and Rangataua can be left open to provide ventilation, and, in times of flash flooding (which can strike during any season), Rangataua becomes a place of retreat for those impacted by the rising waters. Each coat of paint and each raw material used in construction (earth) shelters dwellers from the clemency and inclemency of the weather. Thus, the wharenui gather both earth and sky.

The wharenui gathers mortals. It is important to remember Heidegger's statement that the finite nature of life is something to be celebrated, not avoided. The wharenui is the central point of the marae complex around which mortals (whānau members) gather. It is a reminder of lives lived towards death (to adopt Sharr's [2007] phrasing), because the wharenui is a physical representation of an eponymous ancestor (Tapsell 2002, 142). The structure of the meeting house literally and figuratively embodies an ancestor (see Figure 8): the gable represents the arms (known as the maihi), the tāhuhu (ridgepole atop the structure) is the backbone, and the pou tokomanawa (central post) is the heart of the ancestor (O'Connor and Macfarlane 2002, 228). The pou tokomanawa provides a tangible link between earthly mother and heavenly father (Tapsell 2009).

Anthropologist Jeffrey Sissons summarises the symbolic nature of wharenui:

Meeting-houses are today normally conceptualized as complex representations of ancestry. The ridge pole is said to represent the 


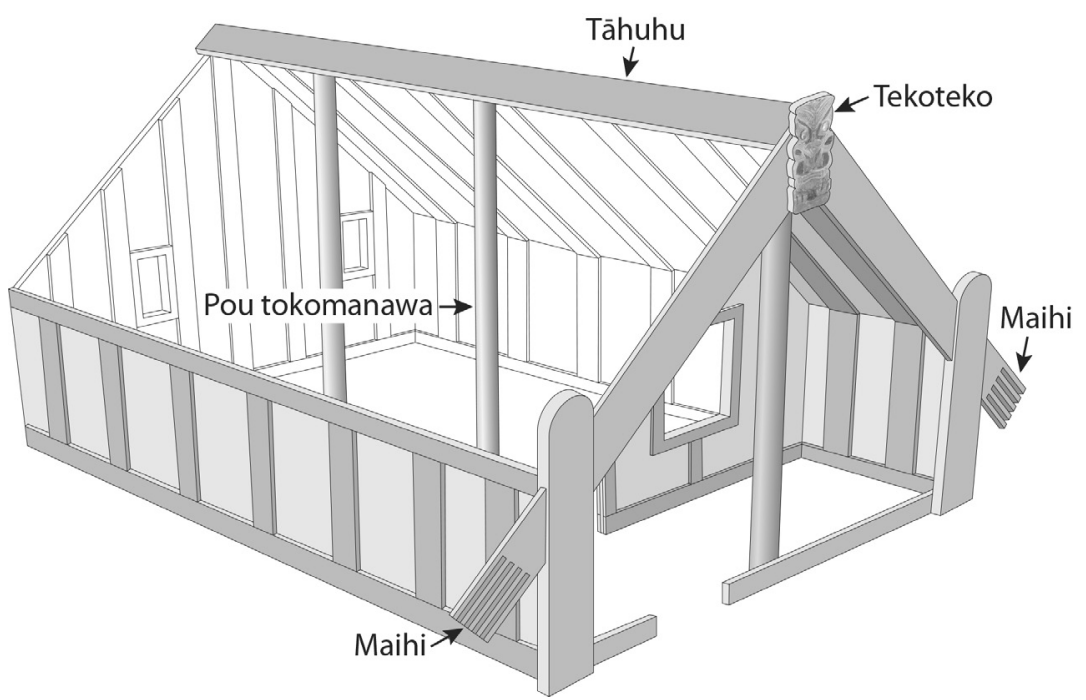

Figure 8. Metaphorical design of a wharenui. Each component represents a part of the body: the tāhuhu represents the backbone; the maihi, the fingers; the pou tokomanawa, the heart; and the tekoteko, the face of the ancestor. Source: Les O'Neill, Department of Anthropology and Archaeology, University of Otago.

origins of descent lines, and carved slabs, evenly spaced around the inside walls, represent significant ancestors. On the apex of the roof and facing visitors as they walk through the gate of the marae is the carved figure or face of an ancestor who typically lived some sixteen to twenty generations ago. The meeting-house [...] is named after this ancestor. $(2010,372)$

When descendants gather in their wharenui, they are literally sheltered within the bosom of their ancestors. The internal walls of the wharenui are usually decorated with images of recent and distant ancestors, mapped out genealogically from whānau to whānau. Upon entering Rangataua and Wairaka, for example, I find that the walls are adorned with photographs of nannas, poppas, aunties, uncles, and cousins who have passed beyond the veil of death. As kin, we celebrate our mortality in the understanding that one day we, too, will join our nannas and poppas as they gaze at the mortal world.

That we gather within the wharenui on a regular basis - for weddings, funerals, twenty-first birthdays, council meetings, or education seminars - denotes 
this celebration of our mortality. In his Black Forest farmhouse, Heidegger poignantly refers to the Totenbaum ('tree of the dead'), a simple log-platform designed to cradle the sarcophagus before burial $(1971,160)$. In the confines of the farmhouse, amidst the commotion of the living, the Totenbaum patiently awaits occupation. In this manner, the 'residents [of the farmhouse] marked out their mortality through rites of passage and routines of daily existence' (Sharr 2007, 68). In Wairaka and Rangataua, equivalents of Heidegger's Totenbaum are present in the metaphorical design of the wharenui as a living ancestor and the guardian tupuna that decorate the interior walls. We do not avoid the inescapable fact of our impermanence but revel in it as we go about our daily lives; and perhaps this is also a reminder to be in and of the world and to realise our potential during our fleeting time on the earth. At the turn of the new millennium, I sat with Poppa as he lay in state within Wairaka and lamented as he fulfilled his rite of passage in making the transition between mortality and eternity. Poppa is now perched on Wairaka's rear wall, just beneath his Mum (my great Nan) and beside his siblings and cousins. Thus, the wharenui gathers mortals. Moe mai rā, Poppa.

Finally, the wharenui gather the divinities. Heidegger refers to this dimension through 'the altar corner behind the community table' in the Black Forest farmhouse $(1971,160)$. To recap, the divinities represent a sense of spiritual reverence (Seamon 2000, 190), and this last essential ingredient of the fourfold is illustrated by Wairaka and Rangataua. As the link between earth and sky, the pou tokomanawa represents Tāne-Māhuta, guardian deity of the forests, who famously separated his primal parents from their eternal embrace. In so doing, Tāne heralded the dawn of light, which, in time, spawned human consciousness. The pou tokomanawa represents the engendering of the mortal world (Tapsell 2009). In this way, the tangible heart-post of the wharenui memorialises the divine origins of humankind. The functional prominence of the pou tokomanawa reinforces this sentiment: the mass of the roof is concentrated upon this weight-bearing column, without which it would collapse in on itself. Thus, the wharenui (and, more broadly, our world, earth, universe, solar system, and galaxy) represents a small pocket of life made possible by Tāne's feat that inaugurated our universe, and it is within this space that mortals gather. This spiritual veneration of our existence, embodied through architecture and cosmology, represents the wharenui's gathering of the divinities, illustrating Ingold's assertion that buildings reflect the worldview of their inhabitants (2000, 186). Providing shelter from the periodic inclemency of the weather, Wairaka and Rangataua have installed the fourfold and allowed 'earth and heaven, divinities and mortals [to] enter in simple oneness' (Heidegger 1971, 160; his emphasis). A place has been created, and the fourfold gathered. 
While examining Wairaka and Rangataua through Heidegger's notions of dwelling and the fourfold is intriguing, this discussion does not escape the reality that the Crown confiscations of land in the 180 os overwhelmed Māori, obliterated platforms of economic self-sustainability, and caused a deluge of negative intergenerational consequences that continue to be felt today (Asher and Naulls 1987; Houkamau 2010; Kawharu 1977; Kawharu, Tapsell, and Woods 2013, 9-10; Williams 1999). For Ngāti Wharepaia, Ngāti Hokopū, and Ngāti Rangataua (hapū of the two marae), this reality is particularly poignant given the Ngāti Awa raupatu (land confiscations by the Crown) in the 1860s, when the Crown confiscated 'some 245,000 acres of [Ngati Awa] lands' (Waitangi Tribunal 1999, 1). The gradual and devastating economic isolation coupled with watershed factors such as the mass urbanisation of kin members following World War II has contributed to whānau becoming more and more isolated as individuals living in the cities, separated from marae life and kin accountability. It is no wonder that Māori today who are born and raised away from their ancestral landscapes 'view tribal marae as distant places to which they feel varying elements of disconnection' (Tapsell and Woods 2008, 198; Tapsell 2002). The ongoing effects of this disconnection are far reaching and are most discernible in disinterested youth and the irregular return of kin to their tūrangawaewae (ancestral place of origin). If dwelling is a process predicated on an intimate involvement with one's environment, then contemporary living destabilised this process. Much of our time is spent working outside of the home (with home ownership further out of reach), food is bought and not grown, and our lives are becoming increasingly self-centred as we are immersed ever deeper into an aggressively neoliberal society. It will be interesting to explore how taurahere marae (marae established outside of their ancestral area, typically in cities) might enhance our understanding of building and dwelling in such circumstances, especially as the majority of Māori live in cities. To varying degrees, the capacity of whānau to dwell (both hau kāinga and kin living afar) is aggravated by this broader economic and socio-political context, and many I spoke with noted, 'we have to do marae work outside of working hours'.

In this light, kin from Wairaka and Rangataua pointed to this 'crisis of people' as the foremost challenge to the survival of marae in the twenty-first century. Whānau today face employment obligations, providing for themselves and their children in an increasingly hostile socio-economic environment, and weekly responsibilities like mortgage or rent payments. It is no stretch of the imagination to envision a world in which whānau find it progressively more 
difficult to be involved with their marae, and, without people dwelling upon the marae, the process of building, preserving, and maintaining the land becomes arduous. Marae gather the fourfold, but this gathering is contingent upon human presence and involvement with the landscape. 'Only if we are capable of dwelling, only then can we build', Heidegger stresses (1971, 160; his emphasis), a troubling thought given the way whānau are dispersed today. Erica shared her wish to have a village settlement around Rangataua for elderly whānau to retire in - to create a residential papakāinga - and, if such a plan materialised, it would be interesting to examine the nature of dwelling and building under such circumstances.

Whether they have chosen to leave their marae or circumstances have forced them, kin who have dispersed are unable to share in the experiences of dwelling and building. Such separation detaches them from tribal lore and knowledge, whanaungatanga (familial connectedness), and the many stories of creation, exploration, adventuring, how 'uncle kills a beast', and how 'nan met koro during the war. Continued physical distance interferes with the ability to imbue the landscape of the marae with meaning and ultimately renders it impossible; it restricts access to repositories of tribal wisdom embedded in the rivers, creeks, oceans, ridgelines, and physical structures that define the marae. It inhibits the layering of experience, abruptly interrupting this genealogy. Like a vehicle running on empty, marae cannot function without the living. It is here that the crisis of marae is most discernible. Inasmuch as the phrases 'I am / ich bin' and 'you are / du bist' signify 'I dwell, you dwell' (Heidegger 1971, 147), the question we must ask ourselves is, Faced with the vicissitudes of modern life, are we still able 'to be' upon our marae, to dwell amongst it, and to build into the future?

\section{CONCLUSION}

Despite all of this, I do not believe that these struggles, such as depopulation, will determine the destiny of our marae. Hundreds of marae communities throughout New Zealand revel in the face of this challenge and have a dedicated cohort of koro, kuia, pakeke (adults), and rangatahi who keep the home fires burning. This is undeniably true of Wairaka and Rangataua, whose hau kāinga continue to expend extraordinary energy in preserving and maintaining their marae. The desire is to encourage whānau (especially youth) to participate in the marae and to reconnect with geographically distant kin. Marae can be places of dwelling, and this discussion has illustrated how wharenui have the ability to install and gather the fourfold. We must continue to find innovative ways to reintegrate kin into their marae so this powerful experience of the 
fourfold is not relegated to the volumes of antiquity. Earth, sky, and divinities are anchored by mortals - by human presence - to give the fourfold life. While dwelling may be a reality for the hau kainga of Wairaka and Rangataua, the ongoing nature of this process, which requires continual input and energy, is greatly encumbered by geographic distance. I share Heidegger's concern that the real problem for us today is not large-scale development projects, but that we have forgotten how to dwell and, therefore, how to build. Evidence of this pandemic in New Zealand can be found in the recent death of a toddler due to substandard living conditions in her state rental home (Miller 2015). By regularly returning to the marae to till the land and cultivate the vine, the hau kāinga of Wairaka and Rangataua are reversing this problem on a micro scale, so that our marae will remain places of dwelling in tomorrow's world. Amidst crisis, opportunity abounds. In meeting the challenges of today, marae communities exhibit resilience and an indomitable will, which galvanises them in resisting the allure of entropy, so that marae will survive the twenty-first century and beyond as enduring symbols of kin identity.

\section{ACKNOWLEDGEMENTS}

I would like to thank my research participants for their patience, time, and energy and rich insights over the course of my Master's degree. I was privileged to spend time with you, and your illuminating stories and perspectives allowed me to write this article. My particular thanks to you, Jo, for always answering my questions and helping out - ōku mihi nui ki a koe e hoa! My sincere thanks go to Bonnie Scarth, for her incredibly helpful suggestions and edits on an early draft, and Emma McGuirk and Strypey Bruce, for numerous intellectually stimulating conversations in the early hours of the morning that helped me to refine my ideas in articulating this argument. My deepest gratitude goes to my Master's supervisors, Associate Professors Jacqui Leckie and Merata Kawharu at the University of Otago, whose continued guidance and direction has been invaluable as I navigate the multitudinous challenges of postgraduate research. I also wish to thank Professor Julie Park, for the continued support as I crafted, edited, and revised this article - oku mihi maioha ki a koe e kuia, ko te ia o te wānanga te awhi nō te tuakana ki te teina. Lastly, thank you again, Cyril, for inspiring me to continue with my writing. I aspire to be half the man you were. Kia pai tō moe i runga i tō moe roa.

\section{NOTES}

1. The Three Minute Thesis (змт) competition is an Australasian event in which postgraduate research students present their research in a three-minute period, 
using creative and innovative methods of communication (although I was disqualified because I was not allowed to present my research as a poem).

2. For more information, see Takotohiwi $(1980,67)$.

3. As the Ngāti Awa tribal council, TRONA is the iwi body that governs and maintains the tribe's collective resources, as gained through the Deed of Settlement in 2002. The resulted from Ngāti Awa's desire for redress regarding the illegal Crown land confiscations in the 1800 . More information can be found at http:// www.ngatiawa.iwi.nz/cms/view/the-settlement.aspx.

4. For access to this episode, see Te Rautau o Rangataua (2008).

\section{REFERENCES}

Asher, George, David Naulls, and New Zealand Planning Council. 1987. Maori Land. Wellington: New Zealand Planning Council.

Aikman-Dodd, Jade. 2013. 'The Relevance of Marae in the Twenty-First Century'. University of Otago 3MT Humanities entry, August.

Basso, Keith H. 1996. Wisdom Sits in Places: Landscape and Language among the Western Apache. Albuquerque: University of New Mexico Press.

Cultural Anthropology. 1988. 'Theme Issue: Place and Voice in Anthropological Theory'. 3 (1).

De Certeau, Michel. 1984. The Practice of Everyday Life. Berkeley: University of California Press.

Fernandez, James. 2003. 'Emergence and Convergence in some African Sacred Places.' In The Anthropology of Space and Place: Locating Culture, edited by Setha M. Low and Denise Lawrence-Zúñiga, 187-203. Oxford: Blackwell Publishing.

Gray, John. 2003. 'Open Spaces and Dwelling Places: Being at Home on Hill Farms in the Scottish Borders.' In The Anthropology of Space and Place: Locating Culture, edited by Setha M. Low and Denise Lawrence-Zúñiga, 224-244. Oxford: Blackwell Publishing. 
Gupta, Akhil, and James Ferguson. 1992. 'Beyond "Culture”: Space, Identity, and the Politics of Difference.' Cultural Anthropology 7, 1:6-23.

- 1997. 'Culture, Power, Place: Ethnography at the End of an Era.' In Culture, Power, Place: Explorations in Critical Anthropology, edited by A. Gupta, and J. Ferguson, 1-32. Durham, NC: Duke University Press.

Harawira, Wena. 1997. Te Kawa o te Marae: A Guide for All Marae Visitors. Auckland: Reed.

Harman, Graham. 2007. Heidegger Explained: From Phenomenon to Thing. Chicago and La Salle, Illinois: Open Court.

Heidegger, Martin. 1971. Poetry, Language, Thought [translated by Albert Hofstadter]. New York: Harper \& Row.

Higgins, Rawinia, and John C. Moorfield. 2004. 'Ngā Tikanga o te Marae: Marae Practices.' In Ki Te Whaiao: An Introduction to Māori Culture and Society, edited by Tania M. Ka’ai, John C. Moorfield, Michael P.J. Reilly, and Sharon Mosley, 72-84. Auckland: Pearson Education.

Houkamau, Carla A. 2010. 'Identity Construction and Reconstruction: The Role of Socio-historical Contexts in Shaping Māori Women's Identity'. Social Identities: Journal for the Study of Race, Nation and Culture 16, 2:179-196.

Ingold, Tim. 200o. The Perception of the Environment: Essays on Livelihood, Dwelling, and Skill. London: Routledge.

Kawharu, Ian H. 1975. Orakei: a Ngati Whatua Community. Wellington: New Zealand Council for Educational Research.

—. 1977. Māori Land Tenure: Studies of a Changing Institution. Oxford: Clarendon Press.

Kawharu, Merata, editor. 2014. Maranga Mai! Te Reo and Marae in Crisis? Auckland: Auckland University Press.

Kawharu, Merata, Paul Tapsell, and Christine Woods. 2013. 'Resistance and Challenge: The Shaping of Indigenous Entrepreneurship, a Maori Context.' Oral Presentation, Hobart: Australian and New Zealand Academy of Management Conference, December. 
King, Michael. 2012 [2003]. The Penguin History of New Zealand. Auckland: Penguin Group.

Legge, Maureen. 2008. 'A Snapshot of Place Based Learning in a Marae Context: an Autoethnographic Account.' New Zealand Journal of Outdoor Education: Ko Tāne Mahuta Pupuke 2, 4:87-102.

Low, Setha M., and Lawrence-Zúñiga, Denise, editors. 2003. The Anthropology of Space and Place: Locating Culture. Oxford: Blackwell Publishing.

Metge, Joan. 1976. The Maoris of New Zealand. London: Routledge.

Miller, Corazon. 2015. 'Damp house led to toddler's death.' New Zealand Herald, June 4, accessed June 15, 2015, http://www.nzherald.co.nz/nz/news/article. cfm?c_id=1\&objectid=11459813\&ref=NZH_FBpage.

Norberg-Schulz, Christian. 1971. Existence, Space and Architecture. London: Studio Vista.

O'Connor, Michael, and Angus Macfarlane. 2002. 'New Zealand Maori Stories and Symbols: Family Value Lessons for Western Councillors.' International Journal for the Advancement of Counselling 24:223-237.

Rodman, Margaret C. 2003. 'Empowering Place: Multilocality and Multivocality'. In The Anthropology of Space and Place: Locating Culture, edited by Setha M. Low and Denise Lawrence-Zúñiga, 204-223. Oxford: Blackwell Publishing.

Salmond, Anne. 1982. 'Theoretical Landscapes: On a Cross-Cultural Conception of Knowledge.' In Semantic Anthropology, edited by David Parkin, 65-87. London: Academic Press.

—. 2009 [1975]. Hui: a Study of Maori Ceremonial Gatherings. North Shore: Penguin Group.

Seamon, David. 2000. 'Concretizing Heidegger's Notion of Dwelling: The Contributions of Thomas Thiis-Evensen and Christopher Alexander.' In Building and Dwelling [Bauen und Wohnen]: Martin Heidegger's Foundation of a Phenomenology of Architecture, edited by Eduard Führ, 189-202. New York: Waxmann.

Sissons, Jeffrey. 2010. 'Building a House Society: the Reorganization of Maori 
Communities around Meeting-houses.' Journal of the Royal Anthropological Institute 16:372-386.

Sharr, Adam. 2007. Heidegger for Architects. London: Routledge.

Steiner, George. 1992. Heidegger. London: Fontana Press.

Takotohiwi, Mihi. 1980. 'Nga Marae o Whakatane: the Marae of Whakatane.' Master's thesis, University of Waikato.

Tapsell, Paul. 2002. 'Marae and Tribal Identity in Urban Aotearoa/New Zealand.' Pacific Studies 25, 1-2:141-169.

—. August 2009. Personal communication. Professor of Māori Studies, University of Otago.

- 2014. 'Tribal Marae: Crisis? What Crisis?' In Maranga Mai! Te Reo and Marae in Crisis?, edited by Merata Kawharu, 35-63. Auckland: Auckland University Press.

Tapsell, Paul, and Christine Woods. 2008. 'Potikitanga: Indigenous Entrepreneurship in a Maori Context.' Journal of Enterprising Communities: People and Places in the Global Economy 2, 3:192-203.

Tauroa, Hiwi, and Patricia Tauroa. 1986. Te Marae: A Guide to Customs \& Protocol. Auckland: Reed Methuen.

Thomas, Julian. 1993. 'The Politics of Vision and the Archaeologies of Landscape.' In Landscape: Politics and Perspectives, edited by Barbara Bender, 19-48. Oxford: Berg.

Te Rautau o Rangataua. 2008. Documentary. Waka Huia Episode 19. New Zealand: TVNZ, Te Māngai Pāho.

Unwin, Simon. 1997. Analysing Architecture. London: Routledge.

Waitangi Tribunal. 1999. WAI46: The Ngati Awa Raupatu Report. Waitangi Tribunal.

Williams, David V. 1999. Te Kooti Tango Whenua: the Native Land Court 1864-1909. Wellington: Huia Publishers. 